University of Nebraska - Lincoln

DigitalCommons@University of Nebraska - Lincoln

Faculty Publications: Department of

Entomology

Entomology, Department of

1991

\title{
The Fatty Acid Compositions of Phospholipids and Triacylglycerols from Two Chinch Bug Species Blissus leucopterus leucopterus and B. iowensis (Insecta: Hemiptera; Lygaeidae) Are Similar to the Characteristic Dipteran Pattern
}

\author{
Barbara P. Spike \\ University of Nebraska \\ Robert J. Wright \\ University of Nebraska, rwright2@unl.edu \\ Stephen D. Danielson \\ University of Nebraska-Lincoln, sdanielson1@unl.edu \\ David W. Stanley-Samuelson \\ University of Nebraska
}

Follow this and additional works at: https://digitalcommons.unl.edu/entomologyfacpub

Part of the Entomology Commons

Spike, Barbara P.; Wright, Robert J.; Danielson, Stephen D.; and Stanley-Samuelson, David W., "The Fatty Acid Compositions of Phospholipids and Triacylglycerols from Two Chinch Bug Species Blissus leucopterus leucopterus and B. iowensis (Insecta: Hemiptera; Lygaeidae) Are Similar to the Characteristic Dipteran Pattern" (1991). Faculty Publications: Department of Entomology. 190.

https://digitalcommons.unl.edu/entomologyfacpub/190

This Article is brought to you for free and open access by the Entomology, Department of at DigitalCommons@University of Nebraska - Lincoln. It has been accepted for inclusion in Faculty Publications: Department of Entomology by an authorized administrator of DigitalCommons@University of Nebraska - Lincoln. 


\title{
The Fatty Acid Compositions of Phospholipids and Triacylglycerols from Two Chinch Bug Species Blissus leucopterus leucopterus and B. iowensis (Insecta: Hemiptera; Lygaeidae) Are Similar to the Characteristic Dipteran Pattern
}

\author{
Barbara P. Spike, Robert J. Wright, Stephen D. Danielson, \\ and David W. Stanley-Samuelson \\ Department of Entomology, University of Nebraska-Lincoln, Lincoln, NE 68583-0816, USA \\ Corresponding author - D. W. Stanley-Samuelson
}

\begin{abstract}
1. The fatty acid compositions of phospholipids and triacylglycerols prepared from whole chinch bugs Blissus leucopterus leucopterus and $B$. iowensis were analyzed.

2. The fatty acid profiles from these insects are different from those from all other insect groups so analyzed, except most Diptera.

3. The major components include 16:0 and 18:0, high proportions of $16: 1$ and 18:1 and low proportions of polyunsaturated fatty acids.

4. The fatty acid profiles were similar for several categories from both species of chinch bugs, including adult males and females, prediapausing and diapausing adults, and nymphs.
\end{abstract}

\section{Introduction}

Stanley-Samuelson et al. (1988) proposed that the fatty acid composition of a given insect may represent an instantaneous window into a large array of ongoing dynamic processes. Among these processes, dietary fatty acids are incorporated into tissues without modifications; also, sugars and certain amino acids are converted into fatty acids, then incorporated into tissues. Tissue fatty acids may be modified by a number of endogenous enzyme systems, including desaturases. In addition to these processes, there is a continuous fatty acid turnover in tissue lipids, brought about by the regulated actions of hydrolytic and transferring enzyme systems.

Whereas these processes enable tremendous short-term changes in fatty acid composition, the bulk of insect fatty acid analyses indicate that most organismal-level profiles are fairly similar (Fast, 1970; Thompson, 1973). Within this broad similarity, certain groups of insects stand out from the general pattern. For example, with the exception of two cecidomyiids, lipids from all dipterans so studied characteristically have high proportions of $16: 1$ (very often $>20 \%$ of total fatty acids, compared with 0-2\% in most insects) (Fast, 1970; Thompson, 1973). Several other distinct patterns have been described for other insect taxa (Fast, 1970; Thompson, 1973; Stanley-Samuelson et al., 1988). These special patterns result from the biochemical processes mentioned above, yet they appear to be fixed features within certain taxonomic groups.

A physiological interpretation of fatty acid compositions would argue that these profiles are not fixed characteristics of insects, but are the end products of adaptive biochemical pro- cesses. If this were so, we would expect that insects would respond to changes in various environmental and life-stage parameters by altering their fatty acid profiles. To be sure, developmental and dietary parameters strongly influence the fatty acid profiles of many insect species (Stanley-Samuelson et al., 1988). If insects are able to respond to changing conditions by altering fatty acid profiles, then the extent of such changes become of interest. Can the fatty acid profiles of insects be modified to only a limited extent, within the boundaries of some template, or might they be radically altered, beyond the patterns commonly seen in representatives of a particular group?

We analyzed the fatty acid compositions of phospholipids (PLs) and triacylglycerols (TGs) from two species of chinch bugs, Blissus leucopterus leucopterus (Say) and B. iowensis (Andre). Our data indicate that chinch bugs present fatty acid profiles very different from all other insects so studied except most Diptera, and that the patterns from B. l. leucopterus do not change during overwintering diapause, development, across gender or after mating. These data show that B. l. leucopterus is an example of an insect that does not undergo remodeling of fatty acid profiles even under extreme changes in environmental conditions and overwintering physiology.

\section{Materials and Methods}

Insects

Chinch bugs, B. l. leucopterus, were collected throughout the late summer, fall and winter of 1989-1990 from fields in Gage County, Nebraska. Prediapausing adults and nymphs were col- 
lected in September from infested millet fields. After mid-October, diapausing adults were collected monthly from native prairie bunchgrasses, mainly little bluestem (Schizachyrium scoparium). Diapause was broken in some adults by transferring them to sorghum Sorghum bicolor in the greenhouse, and allowing them to mate and lay eggs. After 6 weeks, males and females were separated according to morphological characteristics (Luginbill, 1922), then processed for lipid analysis. Groups of the bluestem chinch bug, B. iowensis were collected in July 1990 from buffalograss Buchloe dactyloides on the east campus of the University of NebraskaLincoln. Lipids from nymphs and winged and wingless adult male and females were analyzed.

Identifications of the chinch bug and the bluestem chinch bug were confirmed by the USDA Systematic Entomology Laboratory, Beltsville, Maryland.

\section{Lipid analysis}

Lipids were processed for fatty acid analysis according to routine methods (Howard and Stanley-Samuelson, 1990). Total lipids were extracted by homogenizing groups of 10-20 individuals per sample in chloroform: methanol (2:1, v/v) according to Bligh and Dyer (1959). Autooxidation of unsaturated fatty acids was minimized by adding $50 \mu \mathrm{l}$ of $2 \%$ butylated hydroxytoluene in chloroform to each sample during extraction. PL and TG fractions were prepared from total lipid extracts by developing Silica Gel G thinlayer chromatography plates $[20 \times 20 \mathrm{~cm}, 0.25 \mathrm{~mm}$ thick on glass plates. (Sigma Chemical Co., St Louis, MO)] in petroleum ether: diethyl ether: acetic acid (80:20:1, v/v). Fractions were visualized under u.v. light after spraying with $2^{\prime}, 7^{\prime}$-dichlorofluorescein (Supeico, Supeico Park, PA) and identified by comparison with authentic standards.

Phospholipid and triacylglycerol fractions were scraped from the plates, and transmethylated by refluxing the silica gel in acidified methanol for 90 minutes at $85^{\circ} \mathrm{C}$. Fatty acid methyl esters (FAMEs) were extracted from the acidic methanol three times with petroleum ether, then chromatographed isothermally at $190^{\circ} \mathrm{C}$ on a Hewlett-Packard HP-5890 gas chromatograph (Hewlett-Packard, Palo Alto, CA) equipped with a SP2230 capillary column $[0.25 \mathrm{~mm} \times 30 \mathrm{M}, 0.2 \mu \mathrm{m}$ film thickness (Supeico, Supeico Park, PA)], a flame-ionization detector and an HP-3396A recording integrator. Samples were injected in split mode (45:1), and separations carried out with $\mathrm{He}_{2}$ carrier gas at $0.6 \mathrm{ml} / \mathrm{min}$. Major FAMEs were tentatively identified by comparing retention times with authentic standards (Sigma Chemical, St Louis, MO).
Gas chromatography-mass spectrometry of FAMEs

Identities of FAMEs were confirmed by analysis on capillary GCelectron impact mass spectrometry (EI-MS) on a Hewlett-Packard 5790 GC equipped with an SP-2330 column with specifications exactly as described above (Howard and Stanley-Samuelson, 1990; Stanley-Samuelson et al., 1990). The GC was interfaced to a Hewlett-Packard 5970 mass selective detector operated at $70 \mathrm{eV}$. A 45-s splitless injection was used and all GC runs used temperature programming from 170 to $200^{\circ} \mathrm{C}$ at $1^{\circ} \mathrm{C} / \mathrm{min}$, following an initial 2-min holding period. Separations were carried out with ultrapure $\mathrm{He}_{2}$ at $1 \mathrm{ml} / \mathrm{min}$.

Retention times and total ion EI-mass spectra of even carbonnumber FAMEs were compared with FAME standards obtained from Sigma Chemical Co. Odd carbon-number FAMEs and hydroxy FAMEs were characterized by comparison with published EI-mass spectra (McCloskey, 1970; Ryhage and Stenhagen, 1963).

\section{Results}

\section{Blissus leucopterus leucopterus}

The fatty acid compositions of PLs and TGs prepared from adult males and females, and from nymphs collected before the diapause season, are shown in Table 1. The unusual features of these analyses of chinch bugs are the consistently high proportions of $16: 1$, that make up more than $25 \%$ of PL and more than $35 \%$ of TG fatty acids, respectively, and the very low proportions of polyunsaturated fatty acids (PUFAs). Taken together, the polyenoic components make up less than $3 \%$ of PL fatty acids and do not occur in greater than trace levels in TGs. In addition to the components that are usually seen in insect lipids, we detected small proportions of odd-chain fatty acids.

Chinch bugs can be brought out of diapause by placing them on a suitable host with a long-day photoperiod (16:8, day: night) which induces mating and oviposition (Smith et al., 1981). After 6 weeks, the non-diapausing chinch bugs were processed for fatty acid analysis. The fatty acid compositions of PLs and TGs from diapausing and non-diapausing chinch bugs are shown in Table 2 . These data indicate that the fatty acid profiles from prediapausing, diapausing and non-diapausing chinch bugs are similar.

We analyzed PLs and TGs from three groups of virgin and mated female chinch bugs. Comparisons of virgin and mated females showed that mating status did not alter the PL and TG fatty acid compositions (data not shown).

Table 1. Proportions of fatty acids as percentages of total fatty acids associated with phospholipid and triacylglycerol fractions prepared from prediapausing chinch bug, Blissus leucopterus leucopterus Say

\begin{tabular}{|c|c|c|c|c|c|c|}
\hline \multirow[t]{2}{*}{ Fatty acid } & \multicolumn{3}{|c|}{ Phospholipid } & \multicolumn{3}{|c|}{ Triacylglycerol } \\
\hline & $\begin{array}{r}\text { Male } \\
(n=2)\end{array}$ & $\begin{array}{r}\text { Female } \\
(n=3)\end{array}$ & $\begin{array}{r}\text { Nymph } \\
(n=4)\end{array}$ & $\begin{array}{r}\text { Male } \\
(n=3)\end{array}$ & $\begin{array}{r}\text { Female } \\
(n=4)\end{array}$ & $\begin{array}{r}\text { Nymph } \\
(n=2)\end{array}$ \\
\hline 14:1 & $0.4(0.12)$ & $0.3(0.05)$ & $0.3(0.05)$ & $1.2(0.14)$ & $1.1(0.08)$ & $0.9(0.05)$ \\
\hline 15:0 & $1.2(0.29)$ & $1.1(0.21)$ & $1.2(0.15)$ & $1.6(0.76)$ & 1.5 (1.49) & $2.3(0.40)$ \\
\hline $16: 0$ & $5.4(0.87)$ & 4.7 (0.59) & $4.3(0.30)$ & 18.5 (3.53) & $17.3(3.31)$ & 17.8 (1.05) \\
\hline $16: 1$ & 33.5 (1.87) & 33.9 (1.42) & 33.1 (2.95) & $41.7(3.01)$ & $41.0(1.85)$ & $36.8(1.50)$ \\
\hline 18:2 & $1.1(0.14)$ & $0.7(0.26)$ & $0.6(0.20)$ & $0.2(0.12)$ & $0.1(0.00)$ & $0.1(0.01)$ \\
\hline $18: 3 n-6$ & $0.5(0.07)$ & $0.5(0.08)$ & 0.7 (0.15) & $0.1(0.04)$ & $0.1(0.02)$ & $0.1(0.01)$ \\
\hline $18: 3 n-3$ & $0.5(0.07)$ & $0.3(0.05)$ & $0.3(0.00)$ & $\operatorname{tr}(3 / 3)$ & $\operatorname{tr}(3 / 4)$ & $\operatorname{tr}(2 / 2)$ \\
\hline $20: 1$ & $1.1(0.19)$ & $1.1(0.09)$ & $1.4(0.10)$ & $\operatorname{tr}(3 / 3)$ & $\operatorname{tr}(3 / 4)$ & $0.2(0.05)$ \\
\hline $20: 3 n-6$ & $\operatorname{tr}(4 / 4)$ & $0.5(0.15)$ & $0.2(0.00)$ & - & - & $0.1(0.00)$ \\
\hline
\end{tabular}

Values are mean with SD in parentheses, $n=$ Number of samples. $\operatorname{tr}=$ Trace proportions $(<0.1 \%)$, with parenthetical fraction, $x / y$, indicating the number of runs showing peak/number of replicates. 
Table 2. Proportions of fatty acids as percentages of total fatty acids associated with phospholipid and triacylglycerol fractions prepared from nondiapausing and diapausing chinch bugs, Blissus leucopterus leucopterus Say

\begin{tabular}{|c|c|c|c|c|}
\hline \multirow[b]{2}{*}{ Fatty acid } & \multicolumn{2}{|c|}{ Phospholipid } & \multicolumn{2}{|c|}{ Triacylglycerol } \\
\hline & $\begin{array}{r}\text { Non-diapausing } \\
(n=12)\end{array}$ & $\begin{array}{r}\text { Diapausing } \\
(n=11)\end{array}$ & $\begin{array}{r}\text { Non-diapausing } \\
\qquad(n=12)\end{array}$ & $\begin{array}{r}\text { Diapausing } \\
\qquad(n=10)\end{array}$ \\
\hline $14: 1$ & $\operatorname{tr}(9 / 12)$ & $0.2(0.07)$ & $1.0(0.09)$ & $0.9(0.03)$ \\
\hline $15: 0$ & $0.5(0.23)$ & - & $1.7(0.48)$ & - \\
\hline $16: 0$ & $3.1(0.79)$ & $3.5(0.35)$ & $14.5(1.73)$ & $10.2(1.14)$ \\
\hline $16: 1$ & $33.7(3.25)$ & $32.1(1.60)$ & $39.0(2.04)$ & $43.8(1.32)$ \\
\hline $18: 2$ & $0.9(0.44)$ & $0.9(0.19)$ & $\operatorname{tr}(11 / 12)$ & $0.1(0.01)$ \\
\hline $18: 3 n-6$ & $0.4(0.09)$ & $0.8(0.14)$ & $\operatorname{tr}(12 / 12)$ & $0.1(0.03)$ \\
\hline $18: 3 n-3$ & $0.4(0.07)$ & $0.4(0.11)$ & $\operatorname{tr}(12 / 12)$ & $\operatorname{tr}(3 / 10)$ \\
\hline $20: 1$ & $0.6(0.15)$ & $1.2(0.18)$ & $0.1(0.04)$ & $0.1(0.03)$ \\
\hline $20: 3 n-6$ & $0.3(0.08)$ & $0.7(0.16)$ & - & - \\
\hline
\end{tabular}

Values are mean and SD in parentheses, $n=$ Number of samples, $\operatorname{tr}=$ Trace proportions $(<0.1 \%)$, with parenthetical fraction, $x / y$, indicating the number of runs showing peak/number of replicates.

\section{Blissus iowensis}

Fatty acid compositions of PL and TG prepared from nymphs and adult males and females are set out in Table 3. Winged and wingless morphs were analyzed, and because the profiles from both were similar, they are not reported separately. The overall profiles from $B$. iowensis are similar to those from B. l. leucopterus, with high proportions of 16:1 and very low proportions of PUFAs. Traces of odd-chain component and of C20 PUFAs were also recorded in all PL analyses.

\section{Discussion}

The PL and TG fatty acid profiles from B. l. leucopterus and B. iowensis are very similar. Chinch bug PL and TG fatty acid profiles are characterized by high proportions of 16:1 and very low proportions of C18 and C20 PUFAs; as such, these patterns differ from fatty acid compositions known from all other Heteroptera so studied, and are similar only to the patterns known from most species of Diptera (Fast, 1970; Thompson, 1973).

Within the Hemiptera, Homoptera have fatty acid profiles that are considerably different from the majority of insect species (Fast, 1970; Thompson, 1973). Most species in Aphidiodea feature very high proportions of 12:0 and 14:0, and relatively small proportions of 18:2n-6. Coccids are different from other Homoptera with high proportions of 10:0 and 12:0. Heteropterans differ from homopterans because they present fatty acid profiles that are similar to the typical insectan pattern, although we do not have enough data on species in this group to be aware of exceptions (Fast, 1970). The fatty acid profiles of lygaeids, with the exception of the milkweed bug Oncopeltus fasciatus (Dallas) (Kinsella, 1966; Young, 1967), are virtually unknown. The profiles described here are the only analyses of Blissinae, and they are different from most insects. The Lygaeidae is a large family with over 250 North American species. These insects are generally regarded as seed bugs, but the family also includes a tribe of insect predators (Geocorinae), as well as the Blissinae, which feed on plant fluids (Borror et al., 1989). Considerable differences in fatty acid profiles may be expected among the different feeding types. Indeed, among predatory lygaeids, the fatty acid profiles of Geocoris punctipes are very different from the Blissinae, with low proportions of 16:1 (about 7\%) and high proportions of 18:2 (about 40\%) (A. C. Allen, pers. commn).

Our analyses showed odd-chain fatty acids which have only recently been included in reports on insect tissue lipids. These components have been detected in PLs from the beetle Tenebrio molitor L. (Howard and Stanley-Samuelson, 1990) and from the cicada Tibicen dealbatus (Stanley-Samuelson et al., 1990). Taken

Table 3. Proportions of fatty acids as percentages of total fatty acids associated with phospholipid and triacylglycerol fractions prepared from the bluestem chinch bug, Blissus iowensis Andre collected from buffalograss

\begin{tabular}{|c|c|c|c|c|c|c|}
\hline \multirow[t]{2}{*}{ Fatty acid } & \multicolumn{3}{|c|}{ Phospholipid } & \multicolumn{3}{|c|}{ Triacylglycerol } \\
\hline & $\begin{array}{r}\text { Female } \\
(n=3)\end{array}$ & $\begin{array}{r}\text { Male } \\
(n=4)\end{array}$ & $\begin{array}{r}\text { Nymph } \\
(n=1)\end{array}$ & $\begin{array}{r}\text { Female } \\
(n=3)\end{array}$ & $\begin{array}{r}\text { Male } \\
(n=4)\end{array}$ & $\begin{array}{r}\text { Nymph } \\
(n=1)\end{array}$ \\
\hline $14: 1$ & $0.3(0.12)$ & $0.4(0.15)$ & 0.4 & $1.4(0.16)$ & $1.6(0.19)$ & 1.2 \\
\hline $16: 0$ & $4.3(0.25)$ & $4.7(1.04)$ & 3.7 & $19.2(2.64)$ & $16.9(1.82)$ & 22.5 \\
\hline $16: 1$ & $30.3(0.62)$ & $25.6(1.29)$ & 30.1 & $33.7(3.21)$ & $35.0(2.04)$ & 28.9 \\
\hline 18:0 & $3.8(0.62)$ & $4.9(0.57)$ & 4.5 & 4.9 (1.77) & $3.3(0.25)$ & 6.6 \\
\hline $18: 3 n-6$ & $0.2(0.05)$ & $0.3(0.04)$ & - & $0.1(0.04)$ & $0.1(0.00)$ & 0.2 \\
\hline $18: 3 n-3$ & $0.2(0.01)$ & $0.3(0.07)$ & 0.3 & $\operatorname{tr}(3 / 3)$ & $\operatorname{tr}(4 / 4)$ & $\operatorname{tr}$ \\
\hline $20: 1$ & $1.3(0.17)$ & $1.4(0.29)$ & 1.3 & $0.3(0.04)$ & $0.2(0.09)$ & 0.2 \\
\hline $20: 3 n-6$ & $0.3(0.04)$ & $0.2(0.00)$ & 0.2 & $\operatorname{tr}(2 / 3)$ & $\operatorname{tr}(2 / 4)$ & $\operatorname{tr}$ \\
\hline
\end{tabular}

Values are mean and SD in parentheses, $n=$ Number of samples, $\operatorname{tr}=$ Trace proportions $(<0.1 \%)$, with parenthetical fraction, $x / y$, indicating the number of runs showing peak/number of replicates. 
with the recent attention given to the occurrence and significance of eicosanoid-precursor PUFAs in insect lipids (StanleySamuelson and Dadd, 1983; Stanley-Samuelson et al., 1988), the total number of fatty acid components in most insect tissues may be considerably greater than usually recognized. These more recently-recognized components are usually present in relatively small proportions, and some appear only in trace amounts. For the most part, they would be observed only by capillary column gas chromatography and/or mass spectrometry. The biosynthesis and significance of these components are not yet understood, but their presence suggests a very complex picture of fatty acid biochemistry in insects.

To what extent can the patterns seen in these and other insect groups be modified in response to changes in environmental and biological parameters? Some groups, such as the Lepidoptera, are able to considerably modify their fatty acid patterns. Lepidoptera exhibit typical animal fatty acid profiles, characterized by low proportions of 16:1 and high proportions of 18:2n-6 and/or 18:3n-3 (Fast, 1970). However, in total lipids of bollworms, Heliothis zea (Boddie), fatty acid deficient diets produce larvae with much higher proportions of $16: 1$ and 18:1 and much lower proportions of 18:2n-6 than larvae reared on fatty acid replete diets (Barnett and Berger, 1970). Dietary PUFAs similarly effected tissue lipids on the butterfly Pieris brassicae (Turunen, 1973). These changes in dietary parameters affected radical shifts in fatty acid profiles.

Other groups (i.e. Diptera, the Blissinae) show very little change within a characteristic fatty acid template. Diptera, with the exception of two species of cecidomyiids (Fast, 1970 ), characteristically have high proportions of 16:1, as in chinch bugs. Studies of the effects of larval dietary PUFAs on tissue PL fatty acid compositions in adult mosquitos $\mathrm{Cu}$ lex pipiens $\mathrm{L}$. and $C x$. tarsalis showed that increasing levels of dietary PUFAs had only small effects on tissue monounsaturate proportions (Stanley-Samuelson and Dadd, 1983; Dadd et al., 1987). This suggests that the characteristic feature of dipteran fatty acid profiles is not substantially modified by a major environmental constraint, even to the point of complete absence of essential dietary PUFA. Also, choline deficiency impacts on house fly tissue PLs by reducing the proportion of phosphatidylcholine with respect to phosphatidylethanolamine (Bridges and Watts, 1975). These changes in PL composition were reflected in PL fatty acid compositions: PL 16:1 decreased from 47 to $41 \%$ with increased levels of dietary choline. The results from these dipterans show that fatty acid profiles may be altered by changes in environmental and dietary parameters, but the alterations are consistently within the characteristic dipteran pattern.

We observed similar fatty acid profiles in all categories of chinch bugs that we analyzed: nymphs, virgin and mated adult females, adult males, prediapausing, diapausing adults, and adults brought out of diapause. Diapausing adults consistently had higher proportions of 16:1 than their pre- and non-diapausing counterparts, but the overall features of high 16:1 and low PUFA proportions occurred in all cases. Hence, chinch bugs are among those insects that do not radically modify their fatty acid compositions in response to changes in environmental parameters.

Acknowledgements - This article is Paper No. 9474, Journal Series, Nebraska Agricultural Research Division, and Contribution No. 747 of the Department of Entomology, University of Nebraska-Lincoln. This work was supported by the Institute of Agricultural Sciences and Natural Resource and the Department of Entomology, University of Nebraska-Lincoln and by monies from the Nebraska Grain Sorghum Development, Utilization and Marketing Board.

\section{References}

Barnett J. W. and Berger R. S. (1970) Growth and fatty acid composition of bollworms, Heliothis zea (Lepidoptera: Noctuidae) as affected by dietary fats. Ann. Entomol. Soc. Am. 63, 917-924.

Bligh E. G. and Dyer W. J. (1959) A rapid method of total lipid extraction and purification. Can. J. Biochem. Physiol. 37, 911-917.

Borror D. J., Triplehom C. A., and Johnson N. F. (1989) An Introduction to the Study of Insects, 875 pp. Saunders College, Philadelphia.

Bridges R. G. and Watts S. G. (1975) Changes in fatty acid composition of phospholipids and triglycerides of Musca domestica resulting from choline deficiency. J. Insect Physiol. 21, 861-871.

Dadd R. H., Kleinjan J. E., and Stanley-Samuelson D. W. (1987) Polyunsaturated fatty acids of mosquitos reared with single dietary polyunsaturates. Insect Biochem. 17, 7-16.

Fast P. G. (1970) Insect lipids. Prog. Chem. Fats Lipids 11, 181-242.

Howard R. W. and Stanley-Samuelson D. W. (1990) Phospholipid fatty acid composition and arachidonic acid metabolism in selected tissues of adult Tenebrio molitor (Coleoptera: Tenebrionidae). Ann. Entomol. Soc. Am. 83, 975-981.

Kinsella J. E. (1966) Observations on the changing lipid patterns during the life cycle of Oncopeltus fasciatus. Comp. Biochem. Physiol. 17, 1209-1211.

Luginbill P. (1922) Bionomics of the chinch bug. USDA Bull. No. 1016.

McCloskey J. M. (1970) Mass spectrometry of fatty acid derivatives. In Topics in Lipid Chemistry (Edited by Gunston F. E.), Vol. 1, pp. 369-440. Wiley, New York.

Ryhage R. and Stenhagen E. (1963) Mass spectrometry of longchain ester. In Mass Spectrometry of Organic Ions (Edited by McLafferty F. W.), pp. 399-452. Academic Press, New York.

Smith M. T., Wilde G., and Mize T. (1981) Chinch bug: Damage and effects of host plant and photoperiod. Envir. Entomol. 10, 122-124.

Stanley-Samuelson D. W. and Dadd R. H. (1983) Long-chain polyunsaturated fatty acids: Patterns of occurrence in insects. Insect Biochem. 13, 549-558.

Stanley-Samuelson D. W., Howard R. W., and Toolson E. C. (1990) Phospholipid fatty acid composition and arachidonic acid uptake and metabolism by the cicada Tibicen dealbatus (Homoptera: Cicadidae). Comp. Biochem. Physiol. 97B, 285-289.

Stanley-Samuelson D. W., Jurenka R. A., Cripps C., Blomquist G. J., and de Renobales M. (1988) Fatty acids in insects: Composition, metabolism and biological significance. Arch. Insect Biochem. Physiol. 9, 1-33.

Thompson S. N. (1973) A review and comparative characterization of the fatty acid compositions of seven insect orders. Comp. Biochem. Physiol. 45, 467-482.

Turunen S. (1973) Role of labelled dietary fatty acids and acetate in phospholipids during the metamorphosis of Pieris brassicae. J. Insect Physiol. 19, 2327-2340.

Young R. G. (1967) Fatty acids of some arthropods. Cornell University Agr. Exp. Sta. Mem. 401. 15 pp. 